\title{
Modal Words Containing Participle in Arabic
}

\author{
Aliguliyeva L.H \\ Philology faculty \\ Baku Eurasian University \\ Baku, Azerbaijan \\ aliquliyeva@bk.ru
}

\begin{abstract}
The paper focuses on the analysis of the functionality of modal words+participle in Arabic language. The concept of modality has been a subject of debate since long years in linguistics, and the lack of consensus on this subject sets the relevance of the research subject. The main purpose of the research is to investigate and analyze the modal words in Arabic language by the comparative-descriptive and typologicaldescriptive methods, to analyze them in scientific terms, to define their function and status in the Arabic language, and to find semantic peculiarities. In this regard, modal words in the Arabic language are involved in a complex study for the first time in this paper. The ideas and considerations presented upon the study are explained on specific language materials. The author summarizes the findings and analyzes of the study, and concludes at the end of the research that the content of Arabic words based on modal words is directly dependent on the language specificities. The analyzes collected and scientific results obtained are of particular importance related to the modern Arabic language.
\end{abstract}

Keywords-participles; modality; types of meaning; subjective assessment; specific features; Arabic language; modal words.

\section{INTRODUCTION}

Modality is one of the important and topical issues of language theory in modern linguistics as a category. That's why, fundamental research of this complex problem, which covers all levels of language, is of great importance as it is an essential element of any sentence expressing ideas. So that, it is considered to be one of the important semantic categories that creates a link between language facts and non-linguistic reality.

The fact that modality interacts with language facts and non-linguistic reality as the main element of expression in the sentence, and in this regard, its elevation to the important semantic category of the language has been in the center of attention by the linguists over the past decades, and some issues still remain controversial. All of these are the circumstances that make the article relevant.

The main research object of the paper is modal words + participle. The purpose therefore is to reveal semantic meaning and specific peculiarities of modal words + participle in Arabic language within the context of subjective modality in the language system.
The functional features of participles as the expression means of modality are depicted on the basis of the principles based on the analysis of the theoretical knowledge given in the fundamental works of the worldwide linguists; descriptive, comparative and typological-comparative methods have been used during research.

The scientific novelty of the research is the grouping of the modal contents particularly expressing with participles in Arabic language according to the types of meaning defined in the world linguistic system.

When a man expresses an attitude towards objective reality through human language, he speaks and makes judgments based either on subjective or objective thinking. Therefore, he uses all the means of the language to get the desired outcome. And it creates modality in language. "In a more concrete, our speech consists of two layers: we give information about something, we ask something, we motivate a job, and at the same time we express our attitude to what we say willy-nilly. The first is communicativity (communication through language units), the latter is modality (modality is the Latin word "modalis", means method, means)" [1: 380]. Modality, considered both as logical - philosophical and grammar category, has a broad sense of grammatical meaning predictability, probability, suspicion, aggregation, feasibility and so on.

Enough material has been collected related to the research of modality in world's linguistic for many years. As to the Arabian Grammatists, the modality have not yet been systematically explored as a special category, its essence, semantic structure, and complex description of expression means hasn't been determined by them.

V.N. Yarseva explains modality in her linguistic encyclopedia as a functional-semantic category "Modality (from Lat. Modalis means modal; Lat. Modus is a measure, method) is a functional-semantic category expressing different types of attitude to reality, as well as different types of subjective qualifications reported. Modality is a language universal, it belongs to the main categories of natural language" [2: 303].

One of the founders of the theory of modality, Vinagradov considers modality as a subject-object category and called it an integral part and constructive sign of the sentence "Any 
coherent expression of thoughts, feelings, promptings, reflecting reality in one or another form of sayings, puts on one of the intonation schemes of the sentence that exist in this language system and expresses one of those syntactic meanings that forms a modality category in its totality" [3: $55]$.

Although Vinakradov's researches related to the modalities were based on Russian materials, the results he achieved in that area exceeded the grammar of a language and his modality was long-standing in modalism in other languages. Due to Vinakradov, every sentence of the language includes modality, which is defined as a sign of relevance. So, "the category of modality stays in the mainstream of the central language categories" [3: 41-42].

Sh.Ballin's concept of modality had a broader sense in the European linguistics. He has divided a sentence in the language into two parts- dictation and modus. The situation itself is intended at the sentence in the first part. The reaction of the thinking subject to the situation is considered in the second part [4: 44]. Balli describes modality as a syntactic category and underlines the importance of the role of modal verbs. According to Bondarkon, modality is a complex category that combines semantic, morphological and lexical expression [5: 136]. Famous linguists Rozental D.E. and Telenkova M.A. introduces modality as a grammaticalsemantic category, and describes it as an expressionist of the assessment given by the objective reality [6: 180].

\section{MATERIAL AND METHODS}

It should be noted that Arabic linguistics does not almost have the concept of "modality". Qrande does not use the term "modality" in his own "grammatical course in the history of the Arabic language", according to the Arabic grammarians. He notes that if the word of modality expresses a wish, desire, abilities, and importance, then the verb is to be placed after the particle "أن" and should be used as a wish [7: 161]. For example:

I have to do it. (It's important for me to do it)

$$
\text { واجب أن أفعل هذا }
$$

As can be seen from the example, a modality (importance) has been expressed at the participle " واجب " which is a noun of the verb "وجب" and "وأن" was used after the particle "that" and used as a wish. Other Russian linguists also say the same thing making the same position that the verbs used as a wish refer to the actions which have not yet occurred as a rule.

Objective modality is the indispensable sign of any idea. It expresses its attitude to the reality in the reality and nonreality plan. Such modality is reflected in the syntactic context of the sentence and in lexical-grammatical arguments. The subjective modality exists in a formal-grammatical sense, and the assessment of the facts described on its basis stands for the evaluation. This meaning is expressed by the grammatical, lexic-grammatical and intonational means that fall on this or that type of sentence, not by means of the structural scheme and its forms (there are some cases where the subjective modal meaning is objectified at the structure scheme of the sentence). It should be noted that the semantic scope of subjective modality is wider. It should be noted that the semantic scope of subjective modality is wider.

There is no serious border between the meanings of objective and subjective modality and expression in language. It is possible to use the same language tools in the expression of this or other modality. For example, the participle "مكن" in Arabian - "it is possible" may indicate the objective modality that indicates the possibility of action and action in the sentence, as well as the subjective modality of the possibility of the idea expressed in the sentence.

Modality is a logical-grammatical category that confirms or denies the truth, authenticity of the verdict. But its grammatical aspect is wider and more colorful. In grammatical modality it is not enough to confirm or deny the verdict. Reality or suspicion in reality here is manifested in various relationships with reality. Expression of modality in different ways is mainly a matter of modal words. Additionally, modal constructions, which are called intermediate words on the basis of the combination of different words and expressions, can also express modal relationships. Modality can be expressed in many ways by language, with intonation, word sequence, adjectives, and also with the verb forms.

\section{THE MEANING TYPES OF MODALITY IN LINGUISTICS}

Modal words can be divided into two types according to their present state: they can be used both as the main parts of speech and as the modal word; they can be used only as the modal words. The linguist scientist G.Kazimov calls this division as stabilized modal words and unstable modal words [1: 383]. The words which are completely formed as modal words and have no common meaning with any speech belong to the first ones. The non-modal words are the words formed by owning modal feature of the main parts of speech. A number of words are gradually transformed into a modal word in this way.

The reflection of reality at the sentence construction appears in different ways. It's basically available in three levels: simple, problematic, and conclusive. Problematic and strict modality in various systemic languages is analytically analyzed, with the help of analytical feud constructions that reflects the problematic words (particles) and the problematic reality that expresses the relevant modal meanings. This technique is the only one in fluctuating languages with different grade synthesis. Modal words define the reality degree of the sentence for speaker.

As in the world linguistics, there are differences in the definition of the meaning of modal words in Azerbaijani linguistic literature too. Mukhtar Husseinzade identifies four types of modal words: 1) Indicators of the relationship degree to reality. 2) Those who express emotional attitude to the opinion expressed in the sentence. 3) Those who express outcome and attendance. 4) Those who express resemblance and comparisons [8: 266-267]. B. Khalilov adds "modal words expressing row and sequence" to this division [9: 333-334]. 
other hand, this attitude manipulates at the level of desire, wish, probability and suppose. The diversity of modal meanings, their grammatical synonymy, as well as the broad classification of the modal types at lexical level, are one of the key and serious factors that make it difficult to work both in science and in the artistic textuality. J. Lyons classifying the modality mainly in scientific texts determines the modality as the author's attitude to the content of the idea, improves the concept of "attitude" and replaces it with the concept of "subjectivism". Subjectivism is understood as the including (involvement)of the author's personal "I" into the text. Thus, the subject becomes the identity (access point) of modality [12: 237].

The participles create new participles, simple and complex tense forms and modal forms in harmony with modal auxiliary words by accepting different affection. There are certain difficulties in determining the boundaries of the modal meanings of analytical participle forms. However, the determination of the nature of participle composition has great theoretical and practical importance. Any polyfunctional participles that covers the deeper features of the verb has the ability to describe time, types, modality, and other meanings. All of these features appear in synthetic and analytical occurrences.

Regarding the semantic meanings of the modal words including participle in the Azerbaijani language, there are some types of them meaning the source and reference (some say, that's what I said) of the any idea (his/her or other's) and possibility, suppose and suspect (it seems that).

A.V.Kiselyova, who investigates modality relations in the composition of the participle in the English language, identifies two types of subjective modality in these types of sentences: 1) evaluation modality of the degree of confidence of speaker against his idea, the accuracy and reliability of his knowledge ( knowing what was going.., assming that.., considering that.., seeming quite pleased with himself.., looking faintly.., as if anticipating; 2) desire and will modality (wanting this to end.., still hankering after the cash..,) [13, 7].

Bolotov, who demonstrates the lexical and grammatical expression means of modality, has grouped various constructions with adjectives and participles according to the types of meaning expressed. Based on this grouping, it is possible to create the following table:

\begin{tabular}{|c|c|c|}
\hline $\begin{array}{l}\text { Expressing } \\
\text { necessity }\end{array}$ & المطلوب أنْ أنْ..... & $\begin{array}{l}\text { It is necessary that,.. } \\
\text { It is demanded that,... }\end{array}$ \\
\hline $\begin{array}{l}\text { Expressing } \\
\text { possibility. }\end{array}$ & من المستحيل أنّ (أنْ )... & $\begin{array}{l}\text { It is possible that,.. } \\
\text { It is impossible that,... }\end{array}$ \\
\hline $\begin{array}{l}\text { Expressing } \\
\text { (uncertainty) } \\
\text { certainty }\end{array}$ & من المستحيل أنّّ.... & $\begin{array}{l}\text { It is possible that,... } \\
\text { It is impossible that,.. }\end{array}$ \\
\hline $\begin{array}{l}\text { Expressing } \\
\text { reality. }\end{array}$ & 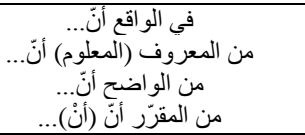 & $\begin{array}{l}\text { It is fact that,.. } \\
\text { It is known that,... } \\
\text { It is clear that,.. } \\
\text { It is decided that,.. }\end{array}$ \\
\hline
\end{tabular}


of the event to the past happens in the syntactical way in both languages with the participation of the auxiliary verb "was""كان":

- It was important to keep her mouth closed.

Dentological modality is a means of determining the level and extent of the occurrence of the event in both scientific and artistic and publicist texts. This type of modality bears a didactic character. It can also express an advice, direction, permission to happen, or barrier.

1) Modal contents expressing probability, reality, ability, skill, possibility (impossibility), probable.

This type of subjective modality has epistemic structure and indicates an evaluation of the probability degree of the relationship between the object of the predicate and its sign by a subject. The evaluating entity considers the existence of this relationship as a result of its own thinking. The level of confidence in the sentence content may differ from the point of view of the speaker.

"If any idea is evaluated from the point of view of its reality, its level of conformity to the reality will be measured by means of expression means expressed in epistemological modality" [15: 30]. It is possible to make such a grouping based on this idea.

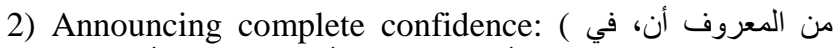
(الواقع أن ، من المعلوم أن، من الواضح أن، من المقرر أن

- It is known that the income from the investment in food is great.

- It is well known that there happens nothing in this point (region) without your consent.

- In truth, they must be subject to development rights.

- It is known that Israel has entered into the conflict without its will.

- من الواضح أن الأمر يتعلق بنائبة الرئيس. Obviously, it is about the vice president.

- من الواضح ان استقلالي العقلي قد هددهم. Obviously, my mental freedom is a threat for them (threatened them).

وبالمثل، من المقرر أن ينتهي التقييم المواضيعي لطرائق التنفيذ في 199V - Similarly, it was decided that thematic evaluation of the terms of the performance would end in February, 1997. (It was also decided that...)

-It was decided the next party would be arrive today.

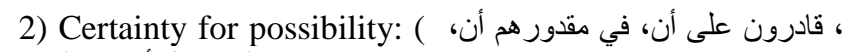

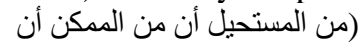

Surely, our resist is possible. (Indeed, it is possible to resist ...) these events does not yet confirm the fact that they will absolutely be happened. It can be unhappened. The reference 
means that the author specifically emphasizes the possibility of the occurrence of the event. The participles in this composition are expressed with the noun verb and nouns formed from the verbs such as "أمكن، قدر، إستحال" "to be possible, to be able, to be impossible". In the sentences of the third section, the degree of certainty is likely to fall to the level of probability (المحتمل). The author probably expresses his or her idea, and the participles in the prepositional modal meaning are expressed with the nouns formed from the verbs "إحتمل، إنتظر، نوقع - " "to suppose, to expect". The author is

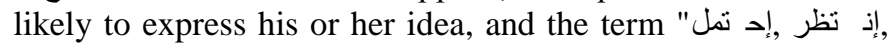
"ت وق ع - "predict, expect" is used to describe the prepositional modal meaning. The denial of these modal combinations is

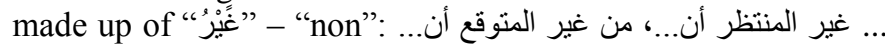
and so on.

It can be concluded from the examples given that the meanings of epistolary modality can be expanded from full certainty to complete uncertainty. In general, for a precise expression of subjective judgment, the level of accuracy of a particular idea should be maximally and unambiguously expressed by the means of modality.

Modal meaning words of desire, wish (إنه راغب في أن.... من لـ انه

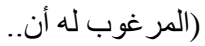

$$
\text { إنه راغب في أن بطر ح بعض الأسئل حول الموضوع. }
$$

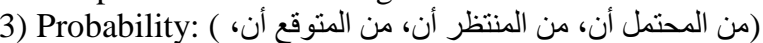

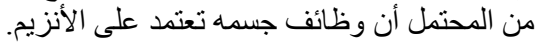

There is a probability of its body being dependent on the enzyme for its acting. (It is likely that ...)

$$
\text { من المحتمل أن الطاقة أستفذت لفترة طويلة. }
$$

(Possibly, energy has exhausted for a long time.) It is possible that the energy has been exhausted for a long time.

$$
\text { ومن المنتظر أن تكون المكاتب في اردن و البرازيل و المكسيك. }
$$

Offices are expected to be located in Jordan, Mexico and Brazil.

ومن المنتظر أن تكتمل مرحلة توزيع البطاقات بحلول 20 نيسان/أبريل.

Distribution of cards is expected to end on April 20. من المتوقع أن تُعتمد نشريعات إضافية خلال السنو ات الأربع المقبلة.

Application of additional laws are envisaged for the next four years.

من المتوقع أن يتم تخفيض عدد الوظائف الأساسية للنظام في ثلاث مر احل.

Reduction of the number of key staff members is expected to be completed in three stages.

In the given sentences, the degree of confidence expressed in modal words with participles shows itself at different levels. Apparently, assurance (المعروف) is expressed at the sentences in the first and the participles in prepositive modal content are عرف ، علم، وقع، وضح، " expressed in noun participles namely "قرر - " to know, to acknowledge, to happen, to be clear, to decide". The author expresses the conviction here that the event comes from the already disclosed conclusion and thus confirms the accuracy of that information. And the possibility (الدمدكن) is highlighted in the second part of sentences, it
He wants to ask a few questions about the subject. (verbatim.

(In real he wants to ask.)

$$
\text { من المرغوب له أن يصبح طبيب أسنان تماما كأبيه }
$$

She wants to be a dentist like her father. (verbatim. It is desirable her being ...)

The modal meaning words here are noun participle and noun meaning " " " "to want, to desire". Since this verb is a transitive verb, the participles formed on its base have a transitive feature and require object. In the sentence constructions above, they substitute verbal predicate by using in the content of principal clause of the the complex sentence having object subordinate clause due to the syntactical position.

\section{CONCLUSION}

Thus, it is possible to conclude from the above studies that the modal compositions formed by the participation of participles are more specific to inflected languages.

Modal words, which are expressed in syntactic structures formed mainly on the ground of complex sentence in the Arabic language, have different meaning types according to the subjective opinion degree of reality. It is possible to say that the deontological and epistological features dominate on the basis of examples given in this respect.

A complex description of participles as a a means of language forming the components of modal words from the functional-semantic point of view is an approach bearing 
practical importance in the research process of modality as a functional-semantic category in general. The material presented in the paper can be used to highlight problems related to the linguistics and modalities in modern Arabic literary language.

\section{References}

[1] Kazımov Q. S. Müasir Azərbaycan dili. Morfologiya. "Nurlan” Bakı. $2010,400$.

[2] Linguistic encyclopedic dictionary. Moscow: Big Russian encyclopedia, 2002. 709.

[3] Vinogradov V. V. About the category of modality and modal words in Russian language. Selected works: Studies in Russian grammar. Moscow. 1975, pp. 53-87

[4] Bally Sh. General linguistics and questions of the French language. Moscow. 1955, 234.

[5] Bondarko A.V. Principles of functional grammar and questions of Aspectology. Moscow: editorial URSS. 2001.

[6] Rosenthal D. E., Telenkova M. A. Dictionary-reference book of linguistic terms. Moscow. 1976, 480.

[7] Grande B. M. Arabic grammar in comparative-historical coverage. Publishing firm "Eastern literature", Moscow. 2001, 592.

[8] M. Hüseynzadə Müasir Azərbaycan dili III hissə. Morfologiya ŞərqQərb, Bak1. 2007, 280.

[9] [9] B. Khalilov Müasir Azərbaycan dilinin morfologiyası, II hissə, “ Papirus NP”, Bak1. 2016352.

[10] F. Zeynalov Türk dillərinin müqyisəli qrammatikası. I hissə, Bakı. 2008, 365.

[11] Q. Rzayev Köməkçi nitq hissələrinin tədrisi. "Şərq-Qərb”, Bakı. 2013, 160.

[12] Lyons J. Semantics. Cambridge University Press. 1977, 897.

[13] Kiselev A. V. The Expression of modality in prepositioned involved in revolutions in modern English URL: http://www.rusnauka.corn/TIP/All/Filology/20.html.

[14] Bolotov V. N. Arabic. Grammar reference. Moscow "Living language". 2009, 224.

[15] Milrud R. p. Antipov I. V. Typological characteristics of modality in the research written text Language and culture. 2009, 1(5), pp. 29-38. 